\title{
ПЕРСПЕКТИВЫ ШЕЛЬФОВЫХ ОТЛОЖЕНИЙ ХАРОСОИМСКОЙ СВИТЫ СЕВЕРО-ЗАПАДНОЙ ЧАСТИ ШАИМСКОГО НЕФТЕГАЗОНОСНОГО РАЙОНА.
}

Залевский О.А. *, Заграновская Д.Е. **, Савенко В.А. **, Гутник О.С. ***

(* - ТПП «Урайнефтегаз, ** - ООО «КогальцнНИПИнефть, *** . . .1О «Батипефте-геофизика»)

В северо-западной части Шаимского НГР в рамках изучения поисковых лицензионных участков $55,60,56$ и 57 Березовской зоны были выполнены поисковые сейсморазведочные работы МОГТ-2Д в объеме 1650 пог км, что в комплексе с переинтерпретащией имеющейся скважинной информации позволило по новому взглянуть на строение неокомского интер-вала отложений Приуральской части Западной Снбири с целью оценки песпектив его нефтегазоносности.

Долгое время считалось, что Уральский источник сноса поставлял в неокомский осадочный бассейн, в отличие от Восточно-Сибирского, преимущественно глинистый мате-риал. Именно эта сложившаяся точка зрения повлияла на то, что до последнего времени в Шаимском НГР неокомский интервал геологического разреза изучался крайне слабо. Но накопленная к настоящему времени сейсмическая и скважинная информация даёт серьёзные основания пересмотреть сушествующий взгляд на полную бесперспективность нижне-меловых отложений Шаимского НГР и перевести их в разряд потенциально перспективных. Перспективы нефтегазоносности неокомских образований в северозападной части Шаимского НГР связаны с двумя объектами: прибрежно-морскими отложениями харосо-имской свиты и одновозрастными, генетически связанными с ними ачимовскими песчани-ками, сформировавшимися в результате транзита шельфовых песчаных отложений в фондоформную часть клиноформного комплекса.

Анализ новой сейсмической информации позволил проследить на временньг разрезах в северозападной части Шаимского НГР клиноформные тела восточного падения, а выполненные палеореконструкщии дали возможность закартировать в пределах полигона исследований границы различных фациальных зон - ундаформ, ортоклиноформ и фондоформ, что соответствует в палеогеоморфологическом плане смене прибрежно - морских условий осадконакопления на склоновые и морские глубоководные соответственно.

На юго-западе рассматриваемой площади, в условия мелководного побережья накапливались песганые отложения харосоимской свиты, которые формировались в ундоформной части клиноформ., Согласно скважинным данным отложения характеризуются хорошими коллекторскими свойствами: открытая пористость изменяется в пределах от 5,8 до $24 \%$, проницаемость от 0,01 до 16,0 мД, водонасышенность от $39,3 \%$, до $94,4 \%$, эффективные толщины выделенных коллекторов изменяются от 1м до 18 м). /1/ К северо-востоку в пределах присклоновых и фондоформных частей клиноформ, являющихся возрастными аналогами мелководных отложений, также можно ожидать наличия песчаных линз ачимовской толщи, сформировавшихся в результате транзита опесчаненных отложений харосо- имской свиты с шельфа в глубоководную часть./2/ Далее на восток отложения харосоимской свиты полностью глинизируются и постепенно переходят в отложения верхнемулымьинской подсвиты.

Песчаники харосоимской свиты в пределах шельфовой террасы являются одним из перспективньгх объектов с точки зрения открытия залежей неструктурного типа. Высокие перспективы этих образований связаны с наличием песчаных линз, которые могут являтся ловушками УВ. Основным инструментом для их изучения послужил динамический анализ на основе сейсмической инверсии, который показал, что фоновый состав рассматриваемых пластов в большей степени глинистый, чем песчаный. Неокомские тонкоотмученные глины обладают минимальными значениями акустического импеданса и появление в разрезе песчаников с улучшенными коллекторскими свойствами вызывает заметные акустические контрасты между слоями и, соответственно, динамические аномалии на сейсмических разрезах.

По разрезам акустического импеданса в пределах шельфовой террасы, вьделены и прослежены в плане линзовидные высокоимпедансные тела, которые, судя по жесткостным характеристикам, являются песчаными.

Учитывая потенциальную перспективность неокомских отложений Шаимского реги-она для поиска новых скоплений углеводородов, необходимы исследования на основе комплексной интерпретации данных МОГТ и ГИС с позиџий сейсмостратиграфия в объём-ном варианте. Также вполне целесообразно и отравданно использовать те методологические приёмы, которые помогают в Среднем Приобье успешно решать задачи поиска песчаньх линз как в пределах шельфовьг, так и клиноформньгх комплексов.

ЛИТЕРАТУРА:

1. Заграновская Д.Е., Савенко В.А., Пасечникова С.Н., Перспективы неокомских отложений в Урайском регионе. Научнотехническая работа. Урай. 2005.-С. 32

2. Нежданов А.А., Пономарёв В.А., Туренков Н.А., Горбубнов С.А., 2000 , Геология и нефтегазоносность ачимовской толщи Западной Сибири: М., Изд-во Академяи горных наук. 